\title{
Work Fatigue Determination of Nurses in Hospital of Hasanuddin University
}

\author{
Asna Ampang Allo ${ }^{1}$, Masyitha Muis ${ }^{1}$, Ansariadi $^{2}$, Atjo Wahyu ${ }^{1}$, Syamsiar S. Russeng ${ }^{1}$, Stang $^{3}$ \\ Corresponding Author Email: asnaampangallo200216@gmail.com \\ ${ }^{1}$ Department of Occupational Safety and Health, Faculty of Public Health, Hasanuddin \\ University, Indonesia \\ ${ }^{2}$ Department of Epidemiology, Faculty of Public Health, Hasanuddin University, Indonesia \\ ${ }^{3}$ Department of Biostatistics, Faculty of Public Health, Hasanuddin University, Indonesia \\ Received: October 18, 2020 \\ Received in Revised: October 26, 2020 \\ Accepted: October 28, 2020
}

\begin{abstract}
This study aims to determine the effect of body mass index (BMI), sleep patterns, working years, physical workload, mental workload, and work time on work fatigue on nurses at Hasanuddin University Hospital Makassar. This research is a quantitative study with a cross-sectional design with a sample size of 56 people. Sampling using a simple random sampling method. Data collection was carried out by means of a questionnaire. Bodyweight is measured by weight scales, body temperature is measured by microtoice, and physical workload is measured by a pulse oximeter, which is by looking at the pulse of the nurse before and after work. Data analysis in this study used the SPSS program. The results of this study indicate that there is an influence between Body Mass Index (BMI) on work fatigue $(\mathrm{p}=0.001)$, there is an effect of sleep patterns on work fatigue $(p=0.019)$, there is an effect of tenure on work fatigue $(p=0.017)$, the relationship between physical workload and work fatigue $(\mathrm{p}=0.000)$, there is an effect of mental workload on work fatigue $(p=0.000)$ and there is an effect of length of work on work fatigue $(p=0.017)$. The physical workload is the variable with the greatest influence on work fatigue on nurses at Hasanuddin University Hospital Makassar with Exp. (B) $=14,526$. The results of this study concluded that there was a significant influence between the Body Mass Index (BMI), sleep patterns, years of work, physical workload, mental workload, and length of work for nurses at Hasanuddin University Hospital Makassar.
\end{abstract}

Keywords: Body Mass Index (BMI), Sleep Patterns, Workload, Length of Work, Work Fatigue

\section{Introduction}

The hospital is a health service facility that provides 24-hour service. The better the hospital service is influenced by the level of productivity of human resources. Nurses are one of the resources needed by hospitals in patient care, where the number of nurses ranks at the top, especially in patient wards. Complex nurse duties can be a heavy burden for nurses in carrying out nursing service tasks to patients who have the opportunity to become stressed (Saparwati \& Apriatmoko, 2020). International Labor Organization (ILO) data reports that $10-50 \%$ of the population in developed countries is exhausted. The prevalence of fatigue is around $20 \%$ among patients who come to need health services and almost every year as many as two million workers die from work accidents caused by fatigue. The study stated that of 58,115 samples, 32.8\% of them 
or 18,828 samples suffered from fatigue (Kusgiyanto et al., 2017).

Work-related fatigue is an important aspect affecting health and safety in the workplace and is recognized as an adverse impact on the quality of care, client or patient satisfaction, and nurse safety. The Canadian Nurses Association defines fatigue in nurses as subjective feelings for nurses' physical and mental health, which are persistent and interfere with a person's physical and mental performance so that they do not function properly. Canadian Nurse Association research report, states that nearly $80 \%$ of nurses in Canada experience fatigue.

In a study conducted by Yu et al (2019) on nurses in the ICU, 36 of 67 (54\%) nurses reported having low/moderate levels of acute fatigue, and 31 people $(46 \%)$ had high levels of fatigue. Research conducted by Dimkatni et al (2020) states that sleep quality is related to the fatigue experienced by nurses, the irregular work schedule of nurses, work shifts that cause changes in sleep patterns in nurses, resulting in a decrease in sleep quality which can cause fatigue. work, decreased concentration, decreased endurance, and less maximal at work. Adequate sleep is needed to reduce work fatigue.

The workload that continues to increase must be supported by the physical condition of a worker, otherwise, it can trigger work fatigue. Fatigue from work will reduce performance and result in errors in work (Maghfiroh \& Mifbakhuddin, 2018). Several studies conducted by the Ministry of Health of the Republic of Indonesia found that as many as 30-40\% of people who work as health service providers who are technicians and work for 8-24 hours per day experience fatigue, this is because there is a rotating work pattern (Trinofiandy et al., 2018).

Hasanuddin University Hospital in Makassar is a Teaching Hospital belonging to Hasanuddin University, which has 853 human resources, consisting of 487 medical personnel and 366 nonmedical personnel who are distributed proportionally to all service units. Based on direct observations made by researchers, it was found that Hasanuddin University Hospital is also one of the hospitals that operate 24 hours, serving BPJS patients and every day is always busy with patient visits, both patients who are residents of Makassar, and patients referred from home sore area. This certainly makes the workload of the nurses bigger, the reduced rest time which can lead to work fatigue on the nurses themselves.

\section{Methods}

The type of research used in this research is observational analytic with a cross-sectional design which aims to see the effect of Body Mass Index (BMI), sleep patterns, years of work, physical workload, mental workload, and length of work on work fatigue in nurses at home. Hasanuddin University Hospital Makassar. The number of samples to be studied was taken using the exhaustive sampling method, which is based on a relatively small population of 56 people, so the entire population was sampled in this study (total sample).

Data collection was carried out through questionnaires and measurements. Body Mass Index (BMI), namely body height measured by microtoice and body weight measured by weight scales. The physical workload is measured with an oximeter. Data on sleep patterns, years of work, mental workload, and length of work were obtained through interviews with nurses at Hasanuddin University Hospital Makassar. The data obtained were analyzed using a computer application. Univariate and bivariate were analyzed using SPSS to determine the ranking, frequency distribution, and influence between the independent and dependent variables. 


\section{Results and Discussion}

Table 1. Frequency Distribution of Body Mass Index (BMI), sleep patterns, years of work, physical workload, mental workload, length of work, and work fatigue of nurses at Hasanuddin University Hospital, Makassar

\begin{tabular}{|c|c|c|c|}
\hline Variable & Category & Frequency (n) & Percentage (\%) \\
\hline \multirow{2}{*}{ Body Mass } & Fat & 30 & 53,6 \\
Index (IMT) & Normal & 26 & 46,4 \\
\cline { 2 - 4 } & Total & $\mathbf{5 6}$ & $\mathbf{1 0 0}$ \\
\hline \multirow{3}{*}{ Sleep Pattern } & Bad & 31 & 55,4 \\
& Good & 25 & 44,6 \\
\cline { 2 - 4 } & Total & $\mathbf{5 6}$ & $\mathbf{1 0 0}$ \\
\hline \multirow{2}{*}{ Years of } & Old & 29 & 51,8 \\
Service & New & 27 & 48,2 \\
\cline { 2 - 4 } & Total & $\mathbf{5 6}$ & $\mathbf{1 0 0}$ \\
\hline \multirow{2}{*}{ Physical Work } & Heavy & 30 & 53,6 \\
Load & Light & 26 & 46,4 \\
\cline { 2 - 4 } & Total & $\mathbf{5 6}$ & $\mathbf{1 0 0}$ \\
\hline \multirow{2}{*}{ Mental Work } & Heavy & 34 & 60,7 \\
Load & Light & 22 & 39,3 \\
\cline { 2 - 4 } & Total & $\mathbf{5 6}$ & $\mathbf{1 0 0}$ \\
\hline \multirow{2}{*}{ Length of } & Not Eligible & 29 & 51,8 \\
working & Eligible & 27 & 48,2 \\
\cline { 2 - 4 } & Total & $\mathbf{5 6}$ & $\mathbf{1 0 0}$ \\
\hline \multirow{3}{*}{ Work Fatigue } & Tired & 31 & 44,4 \\
\cline { 2 - 4 } & Not tired & 25 & $\mathbf{1 0 0}$ \\
\cline { 2 - 4 } & Total & $\mathbf{5 6}$ & \\
\hline
\end{tabular}

Source: Primary Data, 2020

Based on table 1, it was found that of the 56 respondents who experienced work fatigue, as many as 31 people (55\%) and those who did not experience fatigue, were as many as 25 people (44.6\%). Respondents who fall into the fat category, as many as 30 people $(53.6 \%)$ and those who fall into the normal category, namely 26 people (46.4\%) and respondents with poor sleep patterns as many as 31 people (55.4\%) and good sleep patterns of 25 people (44.6\%). Respondents with long working tenure were 29 people $(51.8 \%)$ and those with new tenure were 27 people $(48.2 \%)$. Respondents with heavy physical workloads were 30 people $(53.6 \%)$ and light physical workloads were 26 people $(46.4 \%)$, while respondents with heavy mental workloads were 34 people $(60.7 \%)$ and light mental work, as many as 22 people (39.3\%). Respondents with the length of work did not meet the requirements as many as 29 people $(51.8 \%)$ and 27 people $(48.2 \%)$ who met the requirements.

Table 2. The Relationship between Body Mass Index (BMI) and Work Overload for Nurses at Hasanuddin University Hospital, Makassar

\begin{tabular}{|c|c|c|c|c|}
\hline \multirow{2}{*}{ BMI } & \multicolumn{2}{|c|}{ Work Fatigue } & \multirow{2}{*}{ Total } & $\begin{array}{c}\text { Statistical } \\
\text { Test Results }\end{array}$ \\
\cline { 2 - 3 } & Tired & Not Tired & & Test Ren \\
\hline
\end{tabular}




\begin{tabular}{|c|c|c|c|c|c|c|c|}
\hline & $\mathbf{N}$ & $\mathbf{\%}$ & $\mathbf{N}$ & $\mathbf{\%}$ & $\mathbf{n}$ & $\boldsymbol{\%}$ & \\
\cline { 1 - 6 } Fat & 23 & 76,7 & 7 & 23,3 & 30 & 100 & \multirow{2}{*}{$\mathrm{P}=0,001$} \\
\cline { 1 - 6 } Normal & 8 & 30,8 & 18 & 69,2 & 26 & 100 & \\
\hline Total & $\mathbf{3 1}$ & & $\mathbf{2 5}$ & & $\mathbf{5 6}$ & & \\
\hline
\end{tabular}

Source: Primary Data, 2020

The bivariate analysis in table 2 shows that more work fatigue was experienced by respondents who had a fat BMI, namely 23 people $(76.7 \%)$ while in the normal BMI category who experienced fatigue, as many as 8 people $(30.8 \%)$. The results of data analysis using the Chi-Square test obtained p-value $=0.001$ ( $\mathrm{p}<0.05)$. It can be concluded that the Body Mass Index (BMI) has a significant relationship with work fatigue among nurses at Hasanuddin University Hospital, Makassar.

Table 3. The Relationship between Sleep Patterns and Work Overload in Nurses at Hasanuddin University Hospital in Makassar

\begin{tabular}{|c|c|c|c|c|c|c|c|}
\hline \multirow{2}{*}{$\begin{array}{c}\text { Sleep } \\
\text { Pattern }\end{array}$} & \multicolumn{3}{|c|}{ Work Fatigue } & \multicolumn{2}{c|}{ Total } & \multirow{2}{*}{$\begin{array}{c}\text { Statistical } \\
\text { Test Results }\end{array}$} \\
\cline { 2 - 6 } & Tired & \multicolumn{2}{c|}{ Not Tired } & \multicolumn{2}{|c|}{} \\
\cline { 2 - 6 } & $\mathbf{N}$ & $\mathbf{\%}$ & $\mathbf{N}$ & $\mathbf{\%}$ & $\mathbf{n}$ & $\mathbf{\%}$ & \\
\hline Bad & 22 & 71,0 & 9 & 29,0 & 31 & 100 & \multirow{2}{*}{$\mathrm{P}=0,019$} \\
\hline Good & 9 & 36,0 & 16 & 64,0 & 25 & 100 & \\
\hline Total & $\mathbf{3 1}$ & & $\mathbf{2 5}$ & & $\mathbf{5 6}$ & & \\
\hline
\end{tabular}

Source: Primary Data, 2020

The bivariate analysis in table 3 shows that more work fatigue is experienced by respondents who have bad sleep patterns, namely 22 people $(71.0 \%)$ while sleeping patterns in the good category who experience fatigue, as many as 9 people $(36.0 \%)$. The results of data analysis using the ChiSquare test obtained $\mathrm{p}$-value $=0.019(\mathrm{p}<0.05)$. It was concluded that sleep patterns have a significant relationship with work fatigue on nurses at Hasanuddin University Hospital in Makassar.

Table 4. The Relationship between Working Period and Overworked Work by Nurses at Hasanuddin University Hospital in Makassar

\begin{tabular}{|c|c|c|c|c|c|c|c|}
\hline \multirow{2}{*}{$\begin{array}{c}\text { Years of } \\
\text { service }\end{array}$} & \multicolumn{4}{|c|}{ Work Fatigue } & \multicolumn{2}{c|}{ Total } & \multirow{2}{*}{$\begin{array}{c}\text { Statistical } \\
\text { Test Results }\end{array}$} \\
\cline { 2 - 6 } & \multicolumn{2}{|c|}{ Tired } & \multicolumn{2}{c|}{ Not Tired } & \multicolumn{2}{|c|}{} \\
\cline { 2 - 6 } & $\mathbf{N}$ & $\mathbf{\%}$ & $\mathbf{N}$ & $\mathbf{\%}$ & $\mathbf{n}$ & $\boldsymbol{\%}$ & \\
\hline Old & 21 & 72,4 & 8 & 27,6 & 29 & 100 & \multirow{2}{*}{$\mathrm{P}=0,017$} \\
\hline New & 10 & 37,0 & 17 & 63,0 & 27 & 100 & \\
\hline Total & $\mathbf{3 1}$ & & $\mathbf{2 5}$ & & $\mathbf{5 6}$ & & \\
\hline
\end{tabular}

Source: Primary Data, 2020

The bivariate analysis in table 4 shows that more work fatigue was experienced by respondents with long working tenure, namely 21 people $(72.4 \%)$, while 10 people $(37.0 \%)$ experienced fatigue during work. The results of data analysis using the Chi-Square test obtained p-value $=0.017$ (p $<0.05)$. It is concluded that tenure has a significant relationship with the work fatigue of nurses at Hasanuddin University Hospital in Makassar. 
Table 5. The Relationship between Physical Workload and Work Fatigue in Nurses at Hasanuddin University Hospital, Makassar

\begin{tabular}{|c|c|c|c|c|c|c|c|}
\hline \multirow{2}{*}{$\begin{array}{c}\text { Physical } \\
\text { Workload }\end{array}$} & \multicolumn{4}{|c|}{ Work Fatigue } & \multicolumn{2}{c|}{ Total } & \multirow{2}{*}{$\begin{array}{c}\text { Statistical } \\
\text { Test Results }\end{array}$} \\
\cline { 2 - 6 } & \multicolumn{2}{|c|}{ Tired } & \multicolumn{2}{c|}{ Not Tired } & \multicolumn{2}{|c|}{} \\
\cline { 2 - 6 } & $\mathbf{N}$ & $\mathbf{\%}$ & $\mathbf{N}$ & $\mathbf{\%}$ & $\mathbf{n}$ & $\mathbf{\%}$ & \\
\hline Heavy & 25 & 83,3 & 5 & 16,7 & 30 & 100 & \multirow{2}{*}{$\mathrm{P}=0,000$} \\
\hline Light & 6 & 23,1 & 20 & 76,9 & 26 & 100 & \\
\hline Total & $\mathbf{3 1}$ & & $\mathbf{2 5}$ & & $\mathbf{5 6}$ & & \\
\hline
\end{tabular}

Source: Primary Data, 2020

The bivariate analysis in table 5 shows that more work fatigue is experienced by respondents who have heavy physical workloads, namely 25 people $(83.3 \%)$ while physical workloads in the mild category who experience fatigue, as many as 6 people $(23.1 \%)$. The results of data analysis using the Chi-Square test obtained $\mathrm{p}$-value $=0.000(\mathrm{p}<0.05)$. It is concluded that physical workload has a significant relationship with work fatigue on nurses at Hasanuddin University Hospital in Makassar.

Table 6. Relationship between Mental Workload and Work Fatigue in Nurses at Hasanuddin University Hospital in Makassar

\begin{tabular}{|c|c|c|c|c|c|c|c|}
\hline \multirow{2}{*}{$\begin{array}{c}\text { Mental } \\
\text { Workload }\end{array}$} & \multicolumn{3}{|c|}{ Work Fatigue } & \multicolumn{2}{c|}{ Total } & \multirow{2}{*}{$\begin{array}{c}\text { Statistical } \\
\text { Test Results }\end{array}$} \\
\cline { 2 - 6 } & \multicolumn{2}{|c|}{ Tired } & \multicolumn{2}{c|}{ Not Tired } & \multicolumn{2}{|c|}{} \\
\cline { 2 - 7 } & $\mathbf{N}$ & $\mathbf{\%}$ & $\mathbf{N}$ & $\mathbf{\%}$ & $\mathbf{n}$ & $\mathbf{\%}$ & \\
\hline Heavy & 26 & 76,5 & 8 & 23,5 & 34 & 100 & \multirow{2}{*}{$\mathrm{P}=0,000$} \\
\hline Light & 5 & 22,7 & 17 & 77,3 & 22 & 100 & \\
\hline Total & $\mathbf{3 1}$ & & $\mathbf{2 5}$ & & $\mathbf{5 6}$ & & \\
\hline
\end{tabular}

Source: Primary Data, 2020

The bivariate analysis in table 6 shows that mental workload fatigue was mostly experienced by respondents who had a heavy mental workload, namely 26 people $(76.5 \%)$ while mental workloads in the mild category experienced fatigue, namely 5 people $(22,7 \%)$. The results of data analysis using the Chi-Square test obtained $\mathrm{p}$-value $=0.000(\mathrm{p}<0.05)$. It is concluded that mental workload has a significant relationship with work fatigue among nurses at Hasanuddin University Hospital in Makassar.

Table 7. The Relationship of Length of Work with Work Overtime in Nurses at Hasanuddin University Hospital in Makassar

\begin{tabular}{|c|c|c|c|c|c|c|c|}
\hline \multirow{2}{*}{$\begin{array}{c}\text { Length of } \\
\text { working }\end{array}$} & \multicolumn{3}{|c|}{ Work Fatigue } & \multicolumn{2}{c|}{ Total } & \multirow{2}{*}{$\begin{array}{c}\text { Statistical } \\
\text { Test Results }\end{array}$} \\
\cline { 2 - 6 } & \multicolumn{2}{|c|}{ Tired } & \multicolumn{2}{c|}{ Not Tired } & \multicolumn{2}{|c|}{} \\
\cline { 2 - 7 } & $\mathbf{N}$ & $\mathbf{\%}$ & $\mathbf{N}$ & $\mathbf{\%}$ & $\mathbf{n}$ & $\mathbf{\%}$ & \\
\hline Not Eligible & 21 & 72,4 & 8 & 27,6 & 29 & 100 & \multirow{2}{*}{$\mathrm{P}=0,017$} \\
\hline Qualify & 10 & 37,0 & 17 & 63,0 & 27 & 100 & \\
\hline Total & $\mathbf{3 1}$ & & $\mathbf{2 5}$ & & $\mathbf{5 6}$ & & \\
\hline
\end{tabular}

Source: Primary Data, 2020 
The bivariate analysis in table 7 shows that more work fatigue is experienced by respondents whose working time does not meet the requirements, namely 21 people $(72.4 \%)$ while respondents whose working time meets the requirements and experiences work fatigue, namely as many as 10 people $(37,0 \%)$. The results of data analysis using the Chi-Square test obtained p-value $=0.017$ ( $\mathrm{p}<0.05$ ). It is concluded that the length of work has a significant relationship with the work fatigue of nurses at Hasanuddin University Hospital in Makassar.

Table 8. Multivariate Analysis of Variables Influencing Work Fatigue in Nurses at Hasanuddin University Hospital, Makassar

\begin{tabular}{lccccc}
\hline \multicolumn{1}{c}{ Variable/Stage } & B & S.E. & Wald & Sig. & Exp(B) \\
\hline Stage 3 & & & & & \\
\hline Body Mass Index (BMI) & 2.510 & .996 & 6.344 & .012 & 12.299 \\
\hline Years of service & 2.373 & 1.021 & 5.400 & .020 & 10.728 \\
\hline Physical workload & 2.676 & .958 & 7.799 & .005 & 14.526 \\
\hline Mental workload & 2.544 & 1.008 & 6.367 & .012 & 12.735 \\
\hline Constant & -15.169 & 4.214 & 12.960 & .000 & .000 \\
\hline
\end{tabular}

Source: Primary Data, 2020

The multivariate analysis in table 8 shows that of the six variables included in the multivariate analysis, it shows that the physical workload variable is the variable with the most dominant influence on work fatigue on nurses at Hasanuddin University Hospital Makassar with an Exp (B) value of 14.526 .

Body Mass Index (BMI) has a significant relationship with work fatigue among nurses at Hasanuddin University Hospital, Makassar. The results of this study are in line with the research conducted by (Purnomo, 2020) about the factors related to fatigue of nurses in the ICU and ER which states that there is a strong relationship between nutritional status and fatigue in nurses. Nutritional status Health and workability are closely related to a person's nutritional level because the body needs substances from food for body maintenance, repair of cell damage, and tissue damage. These nutrients are also needed for work and increase in proportion to the weight of a job (Russeng et al., 2019).

A person who is malnourished or more than a normal BMI will quickly feel tired while doing work. If the nutritional status is associated with fatigue, the lack of nutritional status tends to be easier to experience fatigue because of an imbalance in nutritional reserves which will be converted into energy during activity (Suma'mur, 2009), it is also supported by (Suharjo, 2002) which states that if you consume less food, it can cause the body to convert food reserves into energy to do work so that the body will work hard and cause fatigue (Suharjo, 2002). If the energy in the body is not balanced, both quantitatively and qualitatively, the work capacity will be disturbed. A healthy body is needed so that nutrients can be digested and distributed by the organs (Tarwaka, 2015)

Sleep patterns affect work fatigue on nurses at Hasanuddin University Hospital in Makassar. This research is in line with the research conducted by (Dimkatni et al., 2020) on "Do Workload, Work Stress and Sleep Quality Affect Work Fatigue in Hospital Nurses?" the results state that there is a significant relationship between sleep patterns and work fatigue in nurses. Nurses generally have irregular work schedules and cause changing sleep patterns in nurses, resulting in decreased sleep 
quality which can result in work fatigue (Zhang et al., 2016; Fadli \& Amirah, 2020). Since the beginning, the human body has been patterned following the natural cycle, in which all parts of the human body are actively working in the afternoon and at night in a resting state. Therefore, if the body is required to work at night, of course, it must be accompanied by appropriate adjustments and arrangements for work schedules so that workers continue to excel (E. Grandjean, 1997).

The working period affects the work fatigue of nurses at Hasanuddin University Hospital. This research is in line with the research conducted by Fiona Yu entitled "Exploring the Impact of 12hour Shifts on Nurse Fatigue in Intensive Care Units" showing that there is a relationship between nursing experience and acute fatigue in nurses in the ICU room at two hospitals, nurses who are more The length of time working in the ICU room has more experience than the new nurse, so the right way can be done by the hospital to reduce work fatigue on more experienced nurses, namely by involving new nurses in the ICU room to work together. do its job (Yu et al., 2019)

A long working period can have an impact on workers, both positive and negative. The positive effect is that workers will be more experienced and skilled in their work so that they will get used to the existing pressures, and the negative effect is that workers will feel tired and feel bored, especially with monotonous and repetitive work activities (Kusgiyanto et al., 2017).

A long working period can have an impact on workers, both positive and negative. The positive effect is that workers will be more experienced and skilled in their work so that they will get used to the existing pressures, and the negative effect is that workers will feel tired and feel bored, especially with monotonous and repetitive work activities (Tjahayuningtyas, 2019). This research shows that there is an effect of physical workload on work fatigue on nurses at Hasanuddin University Hospital in Makassar, which is directly proportional to the research conducted by Dimkatni et al (2020) which states that there is a significant relationship between physical workload and fatigue in nurses, this is in line with the American Nurses Credentialing Center which states that there is a relationship related to workload and nurse fatigue. A nurse in a hospital carries physical, social, and mental burdens.

The higher the physical workload can decrease the strength and speed of muscle contraction, which indicates that the muscles are getting weaker, which can result in fatigue (Suma'mur, 2009). Every physiological function of the human body can be seen as a rhythmic balance between energy needs (work) and replacing the amount of energy that has been used (rest). Both processes are an integral part of muscle work, heart work, and all other body functions, so it is important to maintain performance and work efficiency, rest time must be done adequately, both between work hours and outside of work hours (rest at night) (E. Grandjean, 1997)

This study shows that mental workload affects work fatigue on nurses at Hasanuddin University Hospital in Makassar. This research is in line with the research conducted by Ghanbary et al (2018) who measured mental workload with NASA TL-X and obtained the results that mental workload has a significant effect on work fatigue on the Administrative Staff of Communication Services Partners, namely by increasing mental workload, work fatigue increases. The workload is reported to have a negative impact on workers' health, long-term illness due to stress, mental stupidity, and fatigue at work, besides that excessive mental workload is also a major cause of work fatigue (Malekpour et al., 2014).

According to a study from the Aragon Institute of Health Science, people who work more than 40 hours per week are at risk of becoming tired and overwhelmed. Working time that exceeds the 
provisions can result in fatigue for nurses (Bae \& Fabry, 2004). Nurses are very likely to work for 12 hours according to the American Nurses Association (ANA) 2009, where this condition describes the nurse has worked more than the stipulated working time (Overtime work). Excess working time can not only cause fatigue, it can also cause anxiety and lack of sleep which can affect the quality of work of nurses in meeting patient needs (Geiger-Brown et al., 2011).

The workload given to workers needs to be adjusted to the psychological and physical abilities of the workers concerned. Nurse workload is the volume of work of nurses in a hospital unit. While the work volume of nurses is the time needed to handle patients per day. If the number of patients increases along with changes in weather and disease epidemiology, it will increase the workload of nurses, causing work fatigue which affects their work performance (Maharja, 2015).

\section{Conclusion}

Based on the results of the study, it can be concluded that the Body Mass Index (BMI), sleep patterns, years of work, physical workload, mental workload, and length of work have a significant effect on work fatigue on nurses at Hasanuddin University Hospital Makassar. The hospital should pay more attention to the food consumed by nurses so that the nutritional needs of nurses can be met, the hospital should manage the nurse's work schedule as well as possible to avoid nurses who have to work more than one shift in 24 hours so that all nurses' working time is evenly distributed and fulfills. requirements, namely 7 (seven) hours in 1 (one) day, in accordance with the provisions of Law of the Republic of Indonesia Number 13 of 2003 concerning Manpower.

\section{References}

Bae, S. H., \& Fabry, D. (2014). Assessing the relationships between nurse work hours/overtime and nurse and patient outcomes: systematic literature review. Nursing outlook, 62(2), $138-156$.

Dimkatni, N. W. (2020). Apakah Beban Kerja, Stres Kerja dan Kualitas Tidur Mempengaruhi Kelelahan Kerja pada Perawat di Rumah Sakit?. Sam Ratulangi Journal of Public Health, 1(1).

E. Grandjean, K. H. E. K. (1997). F itting The Task To The Human. A Textbook of Occupational Ergonomics, Fifth Edition. Journal of Visual Languages \& Computing (Vol. 11). Philadelphia: Taylor \& Francis Inc.

Fadli, M., \& Amirah, A. (2020). The Effect of Quality of Nursing Service to Patients Satisfaction Level in Hospitality of Partial Reliance and Total Hospital of Sundari General Hospital. Journal La Medihealtico, 1(4), 24-32.

Geiger-Brown, J., Trinkoff, A., \& Rogers, V. E. (2011). The impact of work schedules, home, and work demands on self-reported sleep in registered nurses. Journal of Occupational and Environmental Medicine, 53(3), 303-307.

Ghanbary, A., Haghshanas, B., Habibi, E., \& Abedi, M. (2018). The Investigation Relationship between Mental Workload and Occupational Fatigue in the Administrative Staffs of a Communications Service Company. Iranian Journal of Health, Safety \& Environment, 6(1), 1221-1225.

Kusgiyanto, W., Suroto, S., \& Ekawati, E. (2017). Analisis Hubungan Beban Kerja Fisik, Masa Kerja, Usia, Dan Jenis Kelamin Terhadap Tingkat Kelelahan Kerja Pada Pekerja Bagian 
Pembuatan Kulit Lumpia Di Kelurahan Kranggan Kecamatan Semarang Tengah. Jurnal kesehatan masyarakat (E-Journal), 5(5), 413-423..

Maghfiroh, S., \& Mifbakhuddin, M. (2018). Hubungan Toleransi Stres, Shift Kerja dan Status Gizi Dengan Kelelahan Pada Perawat IGD dan ICU (Studi di RSI Sultan Agung Semarang). Jurnal Kesehatan Masyarakat Indonesia, 10(2), 45-53.

Maharja, R. (2015). Analisis Tingkat Kelelahan Kerja Berdasarkan Beban Kerja Fisik Perawat di Instalasi Rawat Inap Rsu Haji Surabaya. The Indonesian Journal of Occupational Safety and Health, 4(1), 93.

Malekpour, F., Malekpour, A. R., Mohammadian, Y., Mohammadpour, Y., Shakarami, A., \& Sheikh Ahmadi, A. (2014). Assessment of mental workload in nursing by using NASATLX. The journal of urmia nursing and midwifery faculty, 11(11), 892-899.

Purnomo, B. T. (2020). The Affecting Factor of Nurse Fatigues in The ICU and ER of Bhayangkara HS. Samsoeri Mertojoso Hospital. The Indonesian Journal of Occupational Safety and Health, 9, 39-47.

Russeng, S. S., Saleh, L. M., \& Thamrin, Y. (2019). Relationship of Noise and Fatigue at Sultan Hasanuddin Airport Apron Workers. EPH-International Journal of Medical and Health Science (ISSN: 2456-6063), 5(12), 01-09.

Saparwati, M., \& Apriatmoko, R. (2020). Gambaran Kejadian Burnout Pada Perawat Di RSUD Ungaran. Pro Health Jurnal Ilmiah Kesehatan, 2(2), 82-86.

Suharjo, B. C. (2002). Membangun Budaya Keselamatan Pasien Dalam Praktik Kedokteran. yogyakarta: Kanisus.

Suma'mur. (2009). Hiegiene Perusahaan dan Keselamatan Kerja. Jakarta: CV Sagung Seto.

Tarwaka. (2015). Ergonomi Industri Dasar-Dasar Pengetahuan Ergonomi Dan Aplikasi di Tempat Kerja. Surakarta: Harapan Press.

Tjahayuningtyas, A. (2019). Faktor Yang Mempengaruhi Keluhan Musculoskeletal Disorders (MSDs) Pada Pekerja Informal. The Indonesian Journal of Occupational Safety and Health, 8(1), 1.

Trinofiandy, R., Kridawati, A., \& Wulandari, P. (2018). Analisis Hubungan Karakteristik Individu , Shift Kerja, dan Masa Kerja dengan Kelelahan Kerja Pada Perawat di Rumah Sakit X Jakarta Timur, 2(2), 204-209.

Yu, F., Somerville, D., \& King, A. (2019). Exploring the impact of 12-hour shifts on nurse fatigue in intensive care units. Applied Nursing Research, 50, 151191.

Zhang, L., Sun, D. M., Li, C. B., \& Tao, M. F. (2016). Influencing factors for sleep quality among shift-working nurses: A cross-sectional study in China using 3-factor Pittsburgh sleep quality index. Asian nursing research, 10(4), 277-282. 